\title{
Effect of bortezomib in combination with cisplatin and 5-fluorouracil on 4T1 breast cancer cells
}

\author{
AZMI YERLIKAYA ${ }^{1}$, SAYIT ALTIKAT $^{2}$, REYHAN IRMAK $^{3}$, FATMA ZEHRA CAVGA $^{3}$, \\ SULTAN AYSUN KOCACAN ${ }^{4}$ and IHSAN BOYACI ${ }^{5}$
}

\author{
${ }^{1}$ Department of Medical Biology, Faculty of Medicine, Dumlupınar University, Kütahya 43100; \\ ${ }^{2}$ Department of Biochemistry, Faculty of Medicine, Dumlupınar University, Kütahya 43100; ${ }^{3}$ Department of Biology, \\ Dumlupınar University, Kütahya 43100; ${ }^{4}$ Kütahya Evliya Çelebi Education and Research Hospital, \\ Department of Radiation Oncology, Dumlupınar University, Kütahya 43100; \\ ${ }^{5}$ İstanbul Medipol University, Vatan Clinic, İstanbul, 34214, Turkey
}

Received March 1, 2013; Accepted April 29, 2013

DOI: $10.3892 / \mathrm{mmr} .2013 .1466$

\begin{abstract}
Bortezomib is a highly selective and reversible inhibitor of the $26 \mathrm{~S}$ proteasome. It has been approved for the treatment of patients with relapsed and refractory multiple myeloma. A number of studies have been conducted to evaluate the activity and safety of bortezomib either alone or in combination with several cytotoxic agents and radiation. In the current study, the efficacy of bortezomib alone or in combination with cisplatin and 5-fluorouracil was evaluated in 4T1 breast cancer cells, a highly metastatic murine cancer cell line. Using MTT assay, $\mathrm{IC}_{50}$ values of cisplatin and 5-fluorouracil were determined to be 14.2 and $8.9 \mu \mathrm{M}$ for cisplatin and 5-fluorouracil, respectively. The effects of different concentrations of cisplatin and 5-fluorouracil in combination with two different concentrations of bortezomib were examined in the 4T1 cells. Statistically significant differences were found when 1 or $5 \mu \mathrm{M}$ cisplatin was combined with 10 or $50 \mathrm{nM}$ bortezomib. Similarly, $1 \mu \mathrm{M} 5$-fluorouracil or $5 \mu \mathrm{M} 5$-fluorouracil in combination with $10 \mathrm{nM}$ bortezomib caused significant cell death as compared to treatment with single agents. However, 1 or $5 \mu \mathrm{M}$ 5-fluorouracil did not potentiate the effects of higher concentrations of bortezomib $(50 \mathrm{nM})$. The effect of the combination of cisplatin, 5-fluorouracil and bortezomib was determined by soft agar assay. It was confirmed that a combination of cisplatin and bortezomib was more effective than each drug as a monotherapy. Therefore, the combination of cisplatin and bortezomib should be tested further in clinical settings.
\end{abstract}

Correspondence to: Dr Azmi Yerlikaya, Department of Medical Biology, Faculty of Medicine, Dumlupınar University, Kutahya 43100, Turkey

E-mail: ayerlikaya@dumlupinar.edu.tr

Key words: bortezomib, cancer, cisplatin, 5-fluorouracil

\section{Introduction}

Bortezomib is a novel and highly selective proteasome inhibitor. It is a dipeptide boronic acid inhibitor, selectively blocking the chymotrypsin-related activity of the proteasome (1). Data from clinical studies showed that the $26 \mathrm{~S}$ proteasome inhibitor bortezomib has therapeutic potential against various types of cancer including breast, colorectal, lymphoma, multiple myeloma, ovarian, pancreatic, prostate and squamous cell carcinomas (2). Findings of previous studies have shown that the proteasome inhibitor bortezomib exhibits antitumor activities by inducing the accumulation of pro-apoptotic proteins or cell cycle inhibitors (such as Phorbol-12-myristate-13-acetate-induced protein 1, BH3 interacting-domain death agonist, Bcl-2associated X protein, $\mathrm{p} 53$, Bcl-2-associated death promoter and cyclin- dependent kinase inhibitors p21 and p27) depending on the cell line used (2-5). In addition, inhibition of the proteasome by bortezomib results in inhibition of the activation of nuclear factor $\kappa$-light-chain-enhancer of activated B cells $(\mathrm{NF} \kappa \mathrm{B})$ by preventing the degradation of I $\mathrm{B}$ (an inhibitor

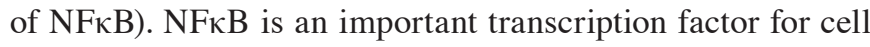
survival $(6,7)$. Therefore, in addition to the stabilization of the above-mentioned pro-apoptotic proteins, bortezomib promotes the apoptosis of cancer cells through inhibition of the activation of NFKB.

In a number of preclinical murine tumor models, bortezomib was identified to exhibit promising antitumor activities as a single agent. LeBlanc et al (8) examined the efficacy, toxicity and in vivo mechanism of action of bortezomib using a human plasmacytoma xenograft mouse model. They observed that the median overall survival was significantly prolonged compared with controls. Their results showed that bortezomib has significant in vivo antimyeloma activity at well-tolerated doses in a murine model. The antitumor activity of bortezomib in combination with other therapies has also been evaluated. For example, Denlinger et al (9) observed that a combined treatment with histone deacetylase inhibitor suberoylanilide hydroxamic acid and bortezomib induced greater reactive oxygen species 
generation and more apoptosis than either drug alone. Teicher et al (10) also evaluated the efficacy of bortezomib in combination with 5-fluorouracil, cisplatin, taxol and adriamycin. Results of that study showed that bortezomib produced primarily additive tumor growth delays against the EMT-6/parent mouse mammary carcinoma grown as a solid tumor subcutaneously in the flanks of female Balb/c mice. The combinations were also highly effective against metastasis to the lungs.

The purpose of this study was to determine the cytotoxic effects of bortezomib, cisplatin and 5-fluorouracil as monotherapies or in combination in a highly metastatic and p53-null 4T1 breast cancer cell line. The results obtained demonstrated that additional studies should be performed on the combination of bortezomib and cisplatin in highly aggressive and metastatic cancers bearing mutated p53 gene.

\section{Materials and methods}

Materials. 3-(4,5-Dimethylthiazol-2-yl)-2,5-diphenyltetrazolium bromide (MTT), RPMI-1640 cell culture media, fetal bovine serum (FBS), trypsin and penicillin/streptomycin were purchased from Sigma-Aldrich (St. Louis, MO, USA). Agarose was from Life Sciences Advanced Technologies, Inc. (St. Petersburg, FL, USA). The Stericup vacuum filtration system was obtained from Millipore Inc., (St. Quentin, France).

Cell culture maintenance. 4T1 breast cancer cells were cultured in RPMI-1640 with 10\% FBS, 10 mM Hepes, 4.5 g/l glucose, $1 \mathrm{mM}$ sodium pyruvate, $0.15 \%$ sodium bicarbonate, $100 \mu \mathrm{g} / \mathrm{ml}$ streptomycin and $100 \mathrm{U} / \mathrm{ml}$ penicillin. Cells were incubated at $37^{\circ} \mathrm{C}$ with $5 \% \mathrm{CO}_{2}$. Stock cultures were grown in $25 \mathrm{~cm}^{2}$ corning flasks and experimental cultures were plated in $60 \times 15$ or $35 \times 10 \mathrm{~mm}$ corning plates.

$I C_{50}$ determination. Fifty thousand cells were seeded in $35 \times 10 \mathrm{~mm}$ plates. After $48 \mathrm{~h}$ of plating, cells were treated with various doses of cisplatin or 5-fluorouracil (0.01, 0.1, 0.5, 1, 10, 50,100 or $200 \mu \mathrm{M}$ ) for $24 \mathrm{~h}$. The cells were incubated for $4 \mathrm{~h}$ with RPMI-1640 media containing $0.5 \% \mathrm{FBS}+0.5 \mathrm{mg} / \mathrm{ml} \mathrm{MTT}$ at $37^{\circ} \mathrm{C}$ with $5 \% \mathrm{CO}_{2}$ to determine the number of surviving cells. After removing the medium containing MTT, the cells were lysed with $3 \% \mathrm{SDS}$ and $40 \mathrm{mM} \mathrm{HCl} /$ isopropanol for $15 \mathrm{~min}$. The lysate was pipetted well to dissolve the MTT-formazan crystals completely and centrifuged at 11,000 x g for $5 \mathrm{~min}$. Absorbance at $570 \mathrm{~nm}$ was recorded with a Bio-Rad (Hercules, CA, USA) Smartspec Plus spectrophotometer $(5,11)$. The $\mathrm{IC}_{50}$ values of each agent were determined with a Prism 3.03 program.

Soft agar assay. Similarly, 100,000 cells were seeded in $60 \times 15 \mathrm{~mm}$ petri dishes. At logarithmic phase, the cells were treated with $10 \mathrm{nM}$ bortezomib, $1 \mu \mathrm{M}$ cisplatin, $1 \mu \mathrm{M}$ 5-fluorouracil or in combination $(1 \mu \mathrm{M}$ cisplatin $+10 \mathrm{nM}$ bortezomib or $1 \mu \mathrm{M}$ fluorouracil $+10 \mathrm{nM}$ bortezomib) for $24 \mathrm{~h}$. After the drug treatment, the cells were counted and $0.75 \mathrm{ml}$ of 2 X RPMI-1640 + 20\% FBS (containing 5,000 cells) was mixed with $0.75 \mathrm{ml}$ of $0.7 \%$ agarose in a tube for each plate. The mixture was added to the base agar containing $0.5 \%$ agar $+1 \mathrm{X}$ RPMI-1640 + 10\% FBS. Plates were incubated for 3 weeks at $37^{\circ} \mathrm{C}$ in a humidified incubator and fed

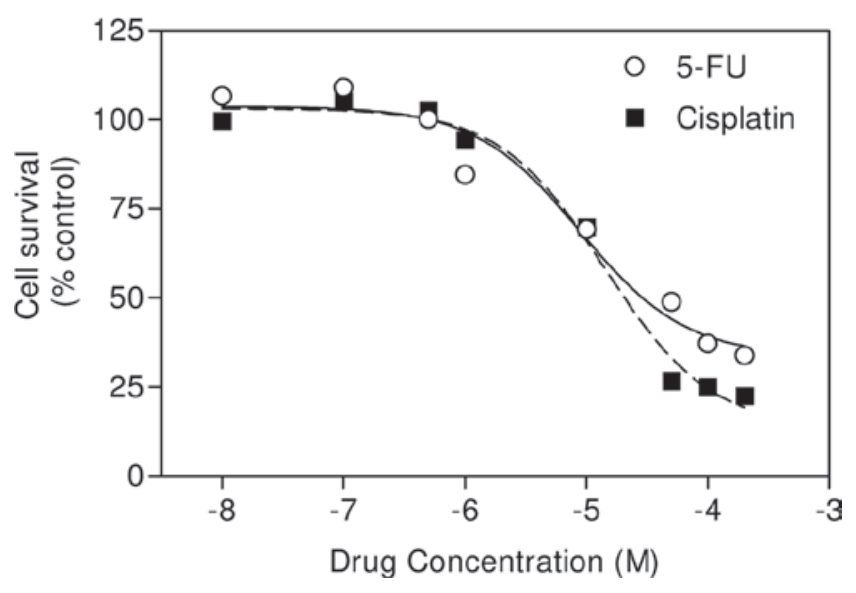

Figure 1. Determination of $\mathrm{IC}_{50}$ values. Cells were treated for $24 \mathrm{~h}$ with various concentrations of cisplatin and 5-fluorouracil (5-FU) as mentioned in the Materials and methods. MTT assay was then used to determine the cell viability (\%). $\mathrm{IC}_{50}$ values were determined after plotting the absorbance values vs. various drug concentrations indicated in Materials and methods using GraphPad Prism 3.03 program. The graph was then fitted with a non-linear regression and sigmoid dose-response curve to obtain the $\mathrm{IC}_{50}$ values $(\mathrm{n}=2)$.

twice a week (12). Plates were then stained with $0.1 \%$ crystal violet in $10 \%$ ethanol for $1 \mathrm{~h}$ and washed extensively with PBS until colonies become apparent for counting.

Statistical analysis. Data were analyzed and presented using GraphPad Prism 3.03 program. One-way ANOVA with the Bonferroni post-test or two-tailed Student's t-test was used to evaluate the statistical significance. $\mathrm{P}<0.05$ was considered to indicate a statistically significant difference.

\section{Results}

Determination of $I_{50}$ values. In previous studies, we determined the p53 status of 4T1 breast cancer cells and verified that they are p53-deficient by examining the induction of both p53 and its downstream target p21 in response to various concentrations of the proteasome inhibitor bortezomib $(5,13)$. Additionally, we identified the $\mathrm{IC}_{50}$ value of bortezomib in 4T1 cells as $71 \mathrm{nM}$, indicating that these p53-deficient cells are sensitive to the inhibition of the proteasome (5). In the present study, we first determined whether the chemotherapeutic agents (cisplatin and 5-fluorouracil) were also cytotoxic to the highly metastatic and p53-null 4T1 breast cancer cells. Results showed that these drugs are highly cytotoxic to $4 \mathrm{~T} 1$ cells (Fig. 1). Using these data, we calculated the $\mathrm{IC}_{50}$ values of cisplatin and 5-fluorouracil to be 14.2 and $8.9 \mu \mathrm{M}$.

Effect of bortezomib and cisplatin combination on cell viability. The effect of the combination of each drug with bortezomib was investigated. Based on the $\mathrm{IC}_{50}$ values, the cells were first treated with two different doses of cisplatin and bortezomib as well as the combinations of each dose tested. As shown in Fig. 2, $1 \mu \mathrm{M}$ cisplatin treatment did not significantly reduce cell survival ( $\mathrm{P}>0.05$ vs. control) after $24 \mathrm{~h}$ of treatment and $5 \mu \mathrm{M}$ treatment of cisplatin caused a $31 \%$ reduction in the cell number $(\mathrm{P}<0.001$ vs. control). 


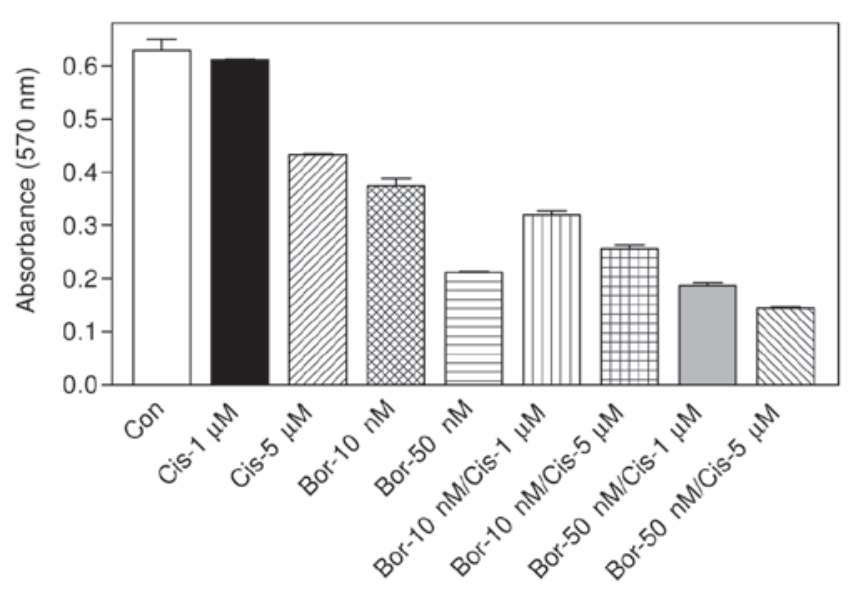

Figure 2. Effect of bortezomib and cisplatin combination on cell viability. Cells were treated with 1 and $5 \mu \mathrm{M}$ cisplatin, 10 and $50 \mathrm{nM}$ bortezomib alone or in combination (i.e., $10 \mathrm{nM}$ bortezomib $+1 \mu \mathrm{M}$ cisplatin; $10 \mathrm{nM}$ bortezomib $+5 \mu \mathrm{M}$ cisplatin; $50 \mathrm{nM}$ bortezomib $+1 \mu \mathrm{M}$ cisplatin; $50 \mathrm{nM}$ bortezomib $+5 \mu \mathrm{M}$ cisplatin) for $24 \mathrm{~h}$. MTT assay was then used to determined the cell viability as described in Materials and methods. The results are shown as the means \pm standard error of the mean $(n=3)$.

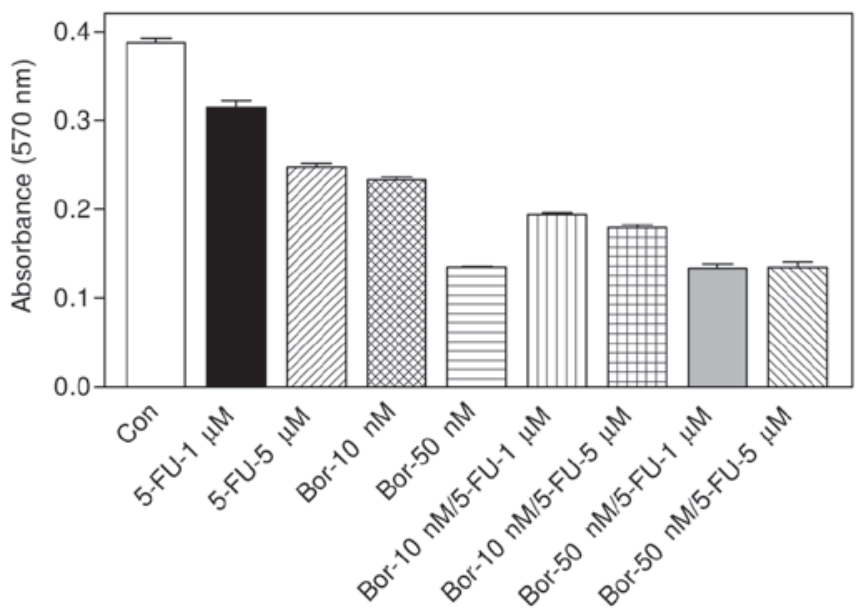

Figure 3. Effect of combination of bortezomib and 5-fluorouracil on cell viability. Cells were treated with 1 and $5 \mu \mathrm{M}$ 5-fluorouracil, 10 and $50 \mathrm{nM}$ bortezomib alone or combinated (i.e., $10 \mathrm{nM}$ bortezomib $+1 \mu \mathrm{M}$ 5-fluorouracil; $10 \mathrm{nM}$ bortezomib $+5 \mu \mathrm{M}$ 5-fluorouracil; $50 \mathrm{nM}$ bortezomib $+1 \mu \mathrm{M}$ 5-fluorouracil; $50 \mathrm{nM}$ bortezomib $+5 \mu \mathrm{M} 5$-fluorouracil) for $24 \mathrm{~h}$. Cell viability was determined with MTT assay as described in Materials and methods. The data are shown as the means \pm standard error of the mean $(n=3)$.

By contrast, $10 \mathrm{nM}$ bortezomib reduced the cell number by $\sim 40 \%$ ( $\mathrm{P}<0.001 \mathrm{vs}$. control), and $50 \mathrm{nM}$ bortezomib resulted in a $66 \%$ reduction in the cell viability $(\mathrm{P}<0.001$ vs. control), altogether indicating that bortezomib is a more cytotoxic agent than cisplatin in this highly mestastatic breast carcinoma cell line. When cells were treated with $10 \mathrm{nM}$ bortezomib $+1 \mu \mathrm{M}$ cisplatin, a statistically significant cell death was observed as compared with single drug treatments (for example, $\mathrm{P}<0.05$ vs. $10 \mathrm{nM}$ treated bortezomib). When a higher concentration $(5 \mu \mathrm{M})$ of cisplatin was combined with $10 \mathrm{nM}$ bortezomib, again more cytotoxicity was detected $(\mathrm{P}<0.001$ vs. $10 \mathrm{nM}$ bortezomib). In cells treated with
A
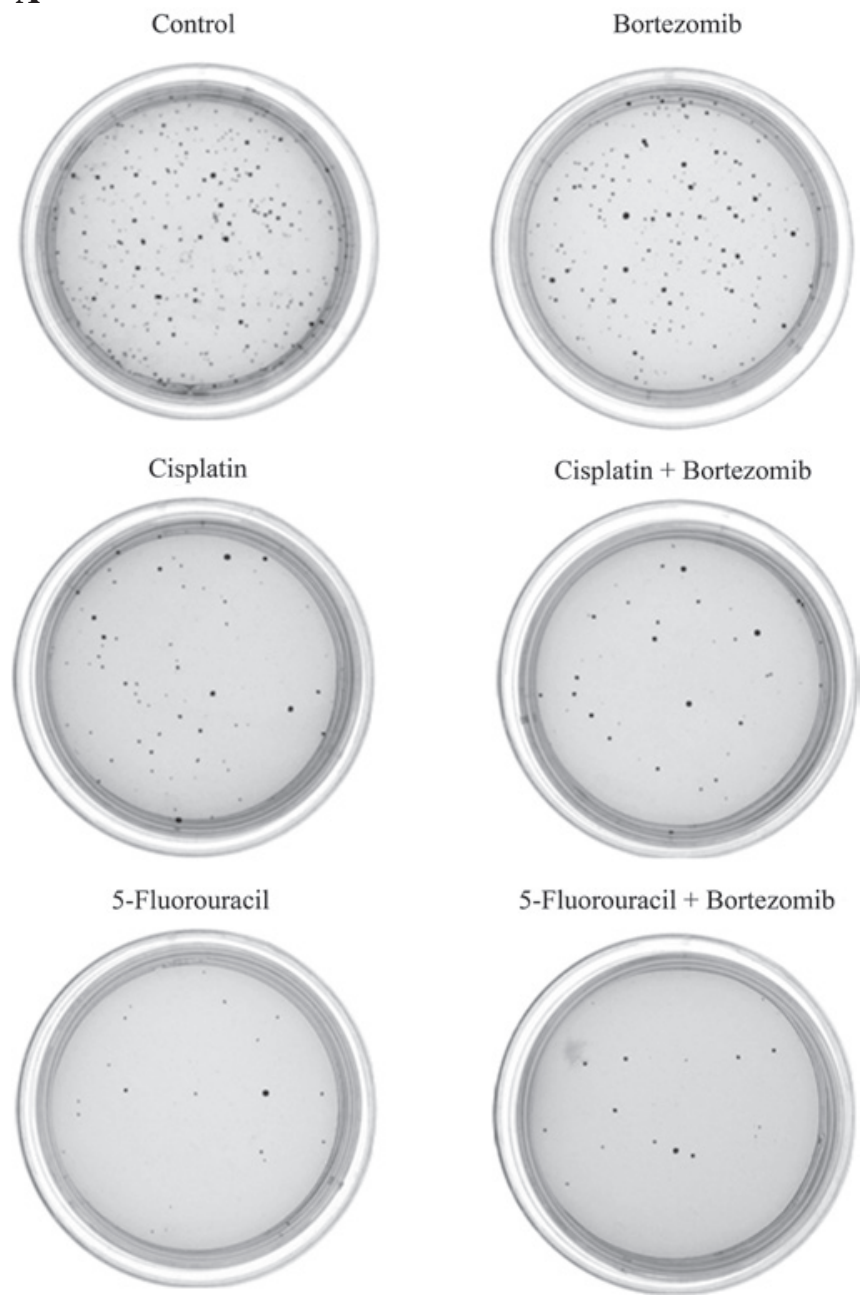

B

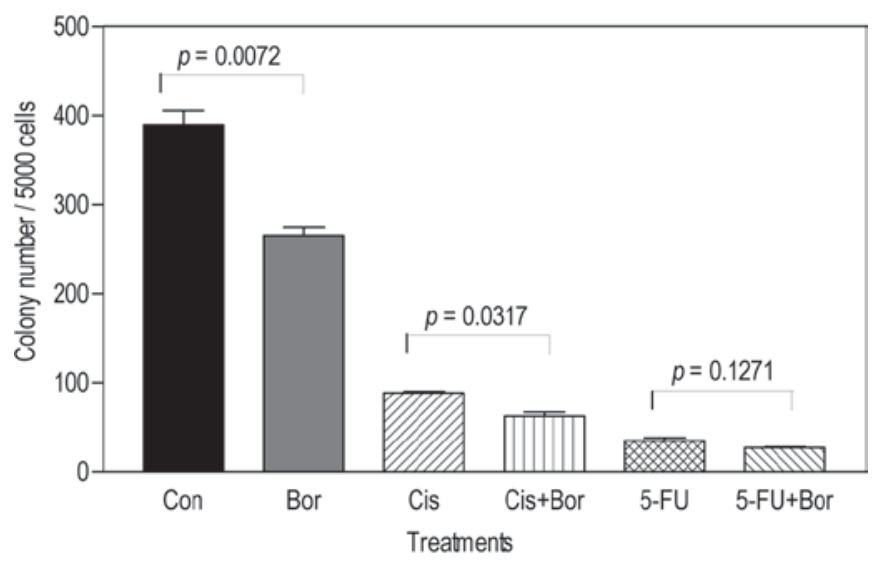

Figure 4. Soft agar assay for the determination of cytotoxicity. (A) Cells were treated with the inhibitors for $2 \mathrm{~h}$. The cells were then mixed with top agarose $(5,000$ cells/plate) and placed on top of a base agar $(0.5 \%)$. The cells were incubated for 3 weeks and then stained with crystal violet $(0.1 \%$ in $10 \% \mathrm{EtOH}$ ) for the colony counting. (B) Cells quantified in (A) are graphed using the GraphPad Prism 3.03 program. A two-tailed Student's t-test was applied to determine the statistical significance between the groups. The data are shown as the means \pm standard error of the mean $(n=2-4)$.

$50 \mathrm{nM}$ bortezomib $+1 \mu \mathrm{M}$ cisplatin, no significant results were observed when compared with $50 \mathrm{nM}$ bortezomib as a monotherapy $(\mathrm{P}>0.05)$. However, when cells were treated 
with $50 \mathrm{nM}+5 \mu \mathrm{M}$ cisplatin, a statistically significant result was obtained as compared with $50 \mathrm{nM}$ bortezomib-treated cells $(\mathrm{P}<0.01)$ (Fig. 2).

Effect of combination of bortezomib and 5-fluorouracil on cell viability. As can be seen in Fig. 3, 1 or $5 \mu \mathrm{M}$ 5-fluorouracil caused significant cell death as compared to the control group $(\mathrm{P}<0.001$ in both cases). However, a 10 or $50 \mathrm{nM}$ concentration of bortezomib was more effective compared with 5-fluorouracil. Results showed that $1 \mu \mathrm{M}$ 5-fluorouracil potentiated the cytotoxicity of $10 \mathrm{nM}$ bortezomib when used in combination $(\mathrm{P}<0.001$ vs. $10 \mathrm{nM}$ bortezomib). Similarly, $10 \mathrm{nM}$ bortezomib $+5 \mu \mathrm{M} 5$-fluorouracil was also more cytotoxic $(\mathrm{P}<0.001$ vs. $10 \mathrm{nM}$ bortezomib). However, the effect of $50 \mathrm{nM}$ bortezomib $+1 \mu \mathrm{M} 5$-fluorouracil was not statistically different compared with the effect of $50 \mathrm{nM}$ bortezomib as a monotherapy $(\mathrm{P}>0.05)$. Similarly, $50 \mathrm{nM}$ bortezomib + $5 \mu \mathrm{M} 5$-fluorouracil did not produce significant cell death as compared with $50 \mathrm{nM}$ bortezomib-treated group $(\mathrm{P}>0.05)$.

Soft agar assay for the determination of cytotoxicity. The effect of the combination of cisplatin or 5-fluorouracil with bortezomib was examined using soft agar assay. Of note, in contrast to the MTT assay results, cells formed a low number of colonies when treated with $1 \mu \mathrm{M}$ cisplatin or $1 \mu \mathrm{M} 5$-fluorouracil alone (Fig. 4A). The colony numbers were lower than those in the plate treated with bortezomib alone. Additionally, the number of colonies in the $10 \mathrm{nM}$ bortezomib $+1 \mu \mathrm{M}$ cisplatin-treated group was significantly lower than that of colonies in the plate treated with $1 \mu \mathrm{M}$ cisplatin alone $(\mathrm{P}=0.0317)$, indicating that cisplatin potentiated the effect of bortezomib (Fig. 4B). By contrast, the number of colonies in the $10 \mathrm{nM}$ bortezomib $+1 \mu \mathrm{M} 5$-fluorouracil-treated plate was not significantly lower than that in the $1 \mu \mathrm{M} 5$-fluorouracil alone-treated plate $(\mathrm{P}=0.1271)$, a result consistent with those obtained with the MTT assay.

\section{Discussion}

The $\mathrm{IC}_{50}$ value of cisplatin, and 5-fluorouracil was previously determined as 43.5 and $10 \mu \mathrm{M}$, respectively, in MCF cells (14-16), which are comparable to the values obtained in this study with the $4 \mathrm{~T} 1$ breast cancer cells. Since we have previously shown that $4 \mathrm{~T} 1$ cells are p53-null cells (5), the present results indicate that these anticancer chemotherapeutic agents are able to induce cell death in 4T1 cells in a p53-independent manner. In terms of the combination treatments, the results have shown that cisplatin + bortezomib is more potent than the combination of bortezomib with 5 -fluorouracil since $5 \mu \mathrm{M}$ cisplatin potentiated the cytotoxic effects of $50 \mathrm{nM}$ bortezomib. By contrast, $5 \mu \mathrm{M} 5$-fluorouracil did not affect the degree of toxicity of $50 \mathrm{nM}$ bortezomib significantly. Cisplatin is a widely used anticancer agent. To the best of our knowledge, combination of the cisplatin and bortezomib has not been previously tested in this metastatic $4 \mathrm{~T} 1$ breast cancer cell line, a cell line commonly used in animal tumor models. In addition, the effect of bortezomib and cisplatin combination has not been widely tested in other breast cancer cells. However, in a study with the EMT-6 murine mammary carcinoma cell line, Teicher et al (10) showed that bortezomib (also known as Velcade or PS-341) increased the tumor cell killing of cisplatin. Based on the results of the MTT assay, we expected more colonies in cisplatin- or 5-fluorouracil alone-treated plates (with $\sim 14$ or 9 times lower concentrations of cisplatin or 5-fluorouracil than the $\mathrm{IC}_{50}$ values, respectively) in soft agar assay. Of note, we observed only a $24 \%$ colony formation in cisplatin-treated plates and $17 \%$ colony formation in 5-fluorouracil-treated plates, which may be due to the irreversible binding of cisplatin or 5-fluorouracil to the cell targets. In $10 \mathrm{nM}$ bortezomib-treated plates, we observed $72 \%$ colony formation, which was consistent with the results obtained with the MTT assay. Since bortezomib is known to be a highly selective and reversible inhibitor of the $26 \mathrm{~S}$ proteasome (17), the discrepancies between the number of colonies in soft agar assay and MTT results obtained for cisplatin and 5-fluorouracil may therefore be explained by the reversibility of the drugs. Similar results may be obtained with other irreversible drugs and the assays used may be taken into account when comparing the efficacy of the drugs.

The data presented in this study suggest that p53-null $4 \mathrm{~T} 1$ cells can be used to delineate the mechanism of p53-independent induction of apoptosis by cisplatin and 5-fluorouracil and bortezomib. The studies also suggest that the combination of cisplatin + bortezomib is more effective and that additional investigations should be conducted in clinical settings.

\section{Acknowledgements}

We would like to thank Prof. Dr. Engin Ulukaya (Uludağ University, Bursa, Turkey) for providing bortezomib.

\section{References}

1. Burger AM and Seth AK: The ubiquitin-mediated protein degradation pathway in cancer: therapeutic implications. Eur J Cancer 40: 2217-2229, 2004.

2. Adams J: The proteasome: a suitable antineoplastic target. Nat Rev Cancer 4: 349-360, 2004.

3. Combaret V, Boyault S, Iacono I, Brejon S, Rousseau R and Puisieux A: Effect of bortezomib on human neuroblastoma: analysis of molecular mechanisms involved in cytotoxicity. Mol Cancer 7: 50, 2008.

4. Pei XY, Dai Y and Grant S: The proteasome inhibitor bortezomib promotes mitochondrial injury and apoptosis induced by the small molecule Bcl-2 inhibitor HA14-1 in multiple myeloma cells. Leukemia 17: 2036-2045, 2003.

5. Yerlikaya A and Erin N: Differential sensitivity of breast cancer and melanoma cells to proteasome inhibitor Velcade. Int J Mol Med 22: 817-823, 2008.

6. Boccadoro M, Morgan G and Cavenagh J: Preclinical evaluation of the proteasome inhibitor bortezomib in cancer therapy. Cancer Cell Int 5: 18, 2005.

7. Sunwoo JB, Chen Z, Dong G, Yeh N, Crowl Bancroft C, Sausville E, Adams J, Elliott $P$ and Van Waes C: Novel proteasome inhibitor PS-341 inhibits activation of nuclear factor-kappa B, cell survival, tumor growth, and angiogenesis in squamous cell carcinoma. Clin Cancer Res 7: 1419-1428, 2001.

8. LeBlanc R, Catley LP, Hideshima T, Lentzsch S, Mitsiades CS, Mitsiades N, Neuberg D, Goloubeva O, Pien CS, Adams J, et al: Proteasome inhibitor PS-341 inhibits human myeloma cell growth in vivo and prolongs survival in a murine model. Cancer Res 62: 4996-5000, 2002.

9. Denlinger CE, Rundall BK and Jones DR: Proteasome inhibition sensitizes non-small cell lung cancer to histone deacetylase inhibitor-induced apoptosis through the generation of reactive oxygen species. J Thorac Cardiovasc Surg 128: 740-748, 2004. 
10. Teicher BA, Ara G, Herbst R, Palombella VJ and Adams J: The proteasome inhibitor PS-341 in cancer therapy. Clin Cancer Res 5: 2638-2645, 1999.

11. Freshney RI (ed): Cytotoxicity. In: Culture of animal cells: a manual of basic techniques. 5th edition. Wiley-Liss, New Jersey, NJ, pp359-374, 2005.

12. Chua BT, Lim SJ, Tham SC, Poh WJ and Ullrich A: Somatic mutation in the ACK1 ubiquitin association domain enhances oncogenic signaling through EGFR regulation in renal cancer derived cells. Mol Oncol 4: 323-334, 2010.

13. Yerlikaya A, Okur E and Ulukaya E: The p53-independent induction of apoptosis in breast cancer cells in response to proteasome inhibitor bortezomib. Tumour Biol 33: 1385-1392, 2012.

14. Basma H, El-Refaey H, Sgagias MK, Cowan KH, Luo X and Cheng PW: BCL-2 antisense and cisplatin combination treatment of MCF-7 breast cancer cells with or without functional p53. J Biomed Sci 12: 999-1011, 2005.
15. Hernandez-Vargas H, Ballestar E, Carmona-Saez $P$, von Kobbe C, Banon-Rodriguez I, Esteller M, Moreno-Bueno G and Palacios J: Transcriptional profiling of MCF7 breast cancer cells in response to 5-fluorouracil: relationship with cell cycle changes and apoptosis, and identification of novel targets of $\mathrm{p} 53$. Int J Cancer 119: 1164-1175, 2006.

16. Plano D, Baquedano Y, Ibanez E, Jimenez I, Palop JA, Spallholz JE and Sanmartin C: Antioxidant-prooxidant properties of a new organoselenium compound library. Molecules 15: 7292-7312, 2010

17. Mimnaugh EG, Xu W, Vos M, Yuan X, Isaacs JS, Bisht KS, Gius D and Neckers L: Simultaneous inhibition of hsp 90 and the proteasome promotes protein ubiquitination, causes endoplasmic reticulum-derived cytosolic vacuolization, and enhances antitumor activity. Mol Cancer Ther 3: 551-566, 2004. 